\title{
INTERACTION OF CATIONIC ANTISEPTICS WITH CARDIOLIPIN-CONTAINING MODEL BACTERIAL MEMBRANES
}

Kholina $\mathrm{EG}^{1,2}$, Bozdaganyan $\mathrm{ME}^{1,2}$, Strakhovskaya $\mathrm{MG}^{1,2}$, Kovalenko IB ${ }^{1,2} \otimes$

${ }^{1}$ Federal Scientific and Clinical Center of Specialized Medical Care and Medical Technology of FMBA, Moscow, Russia

2 Lomonosov Moscow State University, Moscow, Russia

Plasma membrane is one of the major targets for cationic antiseptics (CA). The study was aimed to assess molecular effects of CAs of different chemical classes on cardiolipin-containing regions of bacterial plasma membranes. The study was carried out using coarse-grained molecular modeling. Interaction of CAs, such as miramistin, chlorhexidine, picloxidine, and octenidine, with cardiolipin-containing bilayer was assessed based on the CA coarse-grained models. CAs reduced lipid lateral diffusion coefficients and increased the membrane area per lipid. All CAs, except miramistin, reduced the lipid fatty acid chain order parameters. Adding octenidine at a CA : lipid ratio of $1: 4$ resulted in cardiolipin clustering with subsequent pulling the neutral phosphatidylethanolamine molecules out of the model bilayer. It was found that CAs have the potential for sorption to lipid bilayer, causing clustering of negatively charged lipids. Antiseptic octenidine causes formation of cardiolipin microdomains. Abnormal lateral lipid distribution together with pulling out phosphatidylethanolamine molecules can result in increased lipid bilayer permeability. The most significant reduction of cardiolipin lateral diffusion coefficient by $2.8 \pm 0.4$ times was observed in the presence of CA chlorhexidine at an antiseptic : lipid ratio of $1: 4$.

Keywords: antiseptic, bacterial membrane, molecular modeling, miramistin, chlorhexidine, picloxidine, octenidine

Funding: the research was carried out with the financial support of the Russian Foundation for Basic Research (project № 19-34-90045) and the State assignment "The influence of the lipid composition of bacterial membranes on the processes of interaction with antimicrobial compounds" (code: "Membrane").

Author contribution: Kholina EG - constructing molecular models of studied substances, calculations, manuscript writing; Bozdaganyan ME — calculations, manuscript writing; Strakhovskaya MG - study concept, manuscript writing, analysis of the results; Kovalenko IB - study concept, building a computing infrastructure, manuscript writing, analysis of the results.

Correspondence should be addressed: llya B. Kovalenko

Orekhovyi bulvar, 28, Moscow, 115682; ikovalenko78@gmail.com

Received: 19.07.2021 Accepted: 21.08.2021 Published online: 11.09.2021

DOI: $10.47183 /$ mes.2021.024

\section{ВЗАИМОДЕЙСТВИЕ КАТИОННЫХ АНТИСЕПТИКОВ С КАРДИОЛИПИНСОДЕРЖАЩЕЙ МОДЕЛЬНОЙ БАКТЕРИАЛЬНОЙ МЕМБРАНОЙ}

\author{
Е. Г. Холина ${ }^{1,2}$, М. Е. Боздаганян ${ }^{1,2}$, М. Г. Страховская ${ }^{1,2}$, И. Б. Коваленко ${ }^{1,2} \bowtie$ \\ 1 Федеральный научно-клинический центр специализированных видов медицинской помощи и медицинских технологий Федерального медико-биологического
} агентства, Москва, Россия

${ }^{2}$ Московский государственный университет имени М. В. Ломоносова, Москва, Россия

Плазматическая мембрана является одной из главных мишеней действия катионных антисептиков (КА). Целью исследования было изучить на молекулярном уровне действие относящихся к разным химическим классам КА на кардиолипинсодержащие участки плазматической бактериальной мембраны. Исследование выполнено с применением крупнозернистого молекулярного моделирования. На основе созданных крупнозернистых молекулярных моделей КА, включая мирамистин, хлоргексидин, пиклоксидин и октенидин, изучено их взаимодействие с липидным кардиолипинсодержащим бислоем. КА снижали коэффициенты латеральной диффузии липидов и увеличивали площадь поверхности мембраны, приходящуюся на липид. Кроме мирамистина, все КА снижали параметры порядка жирнокислотных цепей липидов. Добавление октенидина в соотношении КА : липид как 1 : 4 приводило к кластеризации кардиолипина с последующим вырыванием из модельного бислоя нейтральных молекул фоссратилилэтаноламина. Выявлено, что КА обладают способностью сорбироваться на липидном бислое, вызывая кластеризацию отрицательно заряженных липидов. Антисептик октенидин вызывает образование кардиолипиновых микродоменов. Нарушение латерального распределения липидов и вырывание молекул фосфатидилэтаноламина может привести к повышению проницаемости липидного бислоя. Наиболее значимое уменьшение коэффициента латеральной диффузии липида кардиолипина в 2,8 \pm 0,4 раза отмечено в присутствии КА хлоргексидина при соотношении антисептик : липид как $1: 4$.

Ключевые слова: антисептик, бактериальная мембрана, молекулярное моделирование, мирамистин, хлоргексидин, пиклоксидин, октенидин

Финансирование: исследование выполнено при финансовой поддержке РФФИ в рамках научного проекта № 19-34-90045 и государственного задания «Влияние липидного состава бактериальных мембран на процессы взаимодействия с антимикробными соединениями», шифр: «Мембрана».

Вклад авторов: Е. Г. Холина - создание молекулярных моделей исследуемых веществ, проведение расчетов, написание текста статьи; М. Е. Боздаганян проведение расчетов, написание текста статьи; М. Г. Страховская - идея исследования, написание текста статьи, анализ результатов; И. Б. Коваленко идея исследования, создание вычислительной инфраструктуры, написание текста статьи, анализ результатов.

$\triangle$ Для корреспонденции: Илья Борисович Коваленко

ул. Ореховый бульвар, д. 28, 115682, г. Москва; ikovalenko78@gmail.com

Статья получена: 19.07.2021 Статья принята к печати: 21.08.2021 Опубликована онлайн: 11.09.2021

DOI: $10.47183 /$ mes.2021.024

Antiseptics come from one of major groups of compounds extensively used to prevent and combat infectious diseases. Activity of antiseptics is associated with their ability to inhibit the growth (bacteriostatic activity) or inactivate microbial cells (bactericidal activity). Among all antiseptics, cationic compounds, which electrostatically bind to the negatively charged groups of bacterial cell wall components and displace the stabilizing divalent cations, are one of the most effective. Assessment of antiseptic antimicrobial activity revealed rupture of cell membrane with subsequent leakage of intracellular components [1], impairment of cellular metabolism [2, 3], enzyme inhibition, inhibition of electron transport and oxidative phosphorylation $[4,5]$. In particular, electron microscopy showed specific ruptures in bacterial cell walls $[6,7]$. 
Among all CAs, quaternary ammonium compounds (QACs) and biguanides are the largest groups of compounds [8]. The first owe their name to the presence of quaternary nitrogen atom covalently attached to hydrophobic substituent [8]. Miramistin (MIR), carrying single positive charge, is an example of nonheterocyclic QAC. Spatial structure of MIR adopts bent conformation, resembling the hook with its head group tilted back to the long-chain alkyl tail [9]. It is assumed that positively charged nitrogen of MIR interacts with negatively charged phospholipids, which results in abnormal membrane surface charge distribution and incorporation of hydrophobic tails into bacterial membranes, leading to the membrane physical and biological function impairment. Antiseptic octenidine (OCT) is an example of heterocyclic QAC. Here, two pyridinic nitrogen atoms linked via an alkyl bridge have alkylamine substituents in the para-position [10]. OCT, carrying a double positive charge, shows high affinity for lipids forming bacterial membranes, especially for negatively charged cardiolipin (CL). Biguanides are the compounds, in which the amidine group is bonded to the guanidine group to form the $-\mathrm{C}=\mathrm{N}-\mathrm{C}=\mathrm{N}-$ conjugated system. Chlorhexidine $(\mathrm{CHL})$ is the best studied representative of biguanides. The symmetric structure of $\mathrm{CHL}$ consists of two hydrophilic biguanide groups connected by a hydrophobic linker, each of them bound to chlorphenol ring. Spatial conformation in the form of the bracket is typical for $\mathrm{CHL}$ [11]. At physiological $\mathrm{pH}$ values, $\mathrm{CHL}$ molecule carries a double positive charge [10]. CHL has become widely used due to antimicrobial activity against many microorganisms, including a broad range of gram-positive and gram-negative bacteria, viruses and fungi. However, $\mathrm{CHL}$ possesses higher activity against gram-positive bacteria. Some gram-negative species, such as Proteus mirabilis (minimum inhibitory concentration (MIC) is $115 \mathrm{mg} / \mathrm{L}$ ), Providencia stuartii (MIC is $102 \mathrm{mg} / \mathrm{L}$ ), show high resistance to $\mathrm{CHL}$ [12].

Bacterial plasma membrane plays an important role in maintaining cell function and has multiple functions, such as regulation of substance transport and involvement in cell division. Lipids, forming the bacterial plasma membrane, differ in the number of fatty acids and their chain length, number and location of double bonds, structure and charge of hydrophilic part [13]. Neutral phosphatidylethanolamine (PE) and negatively charged phospholipids, phosphatidylglycerol (PG) and CL, which make up at least $15 \%$ of total content, are common for most bacteria [14]. In contrast to PE and PG, CL has a more massive structure due to the presence of two phosphate residues and four fatty acids.

Bacterial plasma membranes are characterized by heterogenic lipid distribution [15]. PE phospholipid is distributed evenly in the cells of a broad range of gram-negative bacteria (Escherichia coli, Salmonella Typhimurium, Pseudomonas putida, Azotobacter vinelandii, Proteus vulgaris), however, localization of those in septa was shown for cells of the Bacillus species [16]. Microdomain formation was shown for anionic lipids. In particular, there are microdomains formed of $\mathrm{CL}$ molecules in the plasma membranes at the cell poles of gram-negative bacteria. It is believed that CL localization at the poles in associated with CL involvement in the cell division processes, in particular, with interaction with cell division proteins DnaA, MinD, FtsA. DnaA is responsible for initiation of DNA replication, MinD, being a part of the MinCDE system, prevents divisome localization to the cell poles, FtsA is a bacterial actin, a protein linker for bacterial tubulin FtsZ, forming the $Z$ ring in the center of the cell. These proteins interact mainly with anionic lipids of bacterial plasma membranes due to the presence of amphipathic motifs enriched in positively charged amino acids [17]. The other important cellular processes, involving $\mathrm{CL}$ due to interaction with proteins, are as follows: energy transfer, osmoadaptation, and protein translocation. X-ray diffraction analysis revealed the presence of $\mathrm{CL}$ in the structures of reactive center and cytochrome $\mathrm{C}$ oxidase of Rhodobacter sphaeroides, formate dehydrogenase and succinate dehydrogenase of E. coli [13]. Colocalization of CL with osmosensory transporter ProP [18], which responds to changes in osmolality by increased transport of organic osmolytes to cell, was found in E. coli; colocalization with Eps system, responsible for export of cholera toxin, was found in Vibrio cholera [19].

Regardless of their amount, experimental data on cationic antiseptic mechanisms of action cannot give a clear answer to the question, what is the root cause of the antiseptics' bactericidal action: membrane disintegration or cell metabolism inhibition. Thus, exact molecular mechanisms of action are poorly understood in this group of antimicrobial substances. Taking into account the earlier suggestion about the potential role of CL molecules as CA binding sites [6], the study was aimed to assess the effects of CAs on the CL-containing bacterial plasma membrane areas by molecular modeling.

\section{METHODS}

Coarse-grained molecular models of CAs were described earlier [20]. To assess the effects of CAs on the model bilayer, the following biguanides were selected: $\mathrm{CHL}$, picloxidine (PIC), and QACs (MIR, OCT). All CAs, except MIR, carry double positive charges. CA chemical structures, partitioned to coarse grains using the MARTINI force field, are presented in Fig. 1. Particle type C1 was selected for description of hydrophobic CA fragments by analogy with lipid parameterization; SC2/ SC3/SC4 were selected for aromatic fragments, and P5 were selected for fragments containing peptide bonds, by analogy with amino acid parameterization in the second version of MARTINI force field. Antiseptics were added to model bilayer in different ratios: CA : lipid $1: 8$ and $1: 4$, in accordance with the concentrations used in medical solutions.

Coarse-grained molecular model of bilayer was built using the CHARMM-GUI MARTINI Maker [21], developed by the research group of Professor Im at Lehigh University (USA), in the MARTINI force field [22]. Plasma membrane model, simulating lipid composition at the bacterial cell poles, consisted of lipids palmitoyl-oleoyl-PE (POPE), POPG and $\mathrm{CL}$, carrying the charge -2 (CDL2), at a ratio 81: $7: 12$ by mass. Coarsegrained molecular dynamics (MD) was calculated using the Gromacs 2019.4 software package (developed by Universities of Uppsala and Stockholm, together with the Royal Institute of Technology, Sweden) [23] during $5 \mu$ for the systems CA : lipid $1: 8$, and during $35 \mu$ s for the systems CA : lipid $1: 4$. Modeling was performed in the NVT ensemble using V-rescale thermostat $(\mathrm{T}=320 \mathrm{~K} ; \tau t=1 \mathrm{ps})$ and Parrinello-Rahman barostat (pref = 1 bar; $\tau p=12$ ps) [23]. MD calculation was performed by adding polarized water [24], with dielectric constant $\varepsilon r=2.5$, and integration step $20 \mathrm{fs}$. Characteristics of model bilayers in the presence of CAs were calculated using the built-in utilities of the Gromacs 2019.4 software package. Area per lipid was calculated with the gmx energy tool, and lateral diffusion coefficients were calculated with the gmx msd tool. Density profiles of the molecular dynamic system components relative to the center of bilayer, radial distribution functions, amount of lipids outside the plane of the bilayer were assessed using our Python script with the use of MDAnalysis library functions. Model membrane thickness was defined based on the density 
A

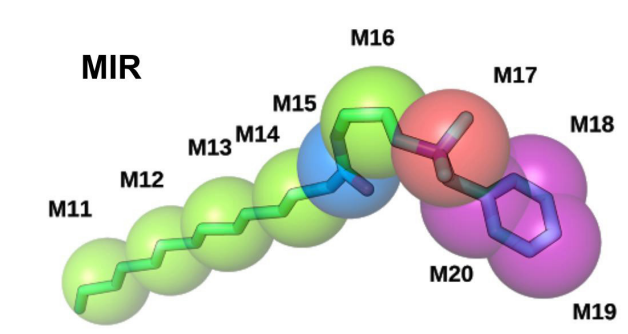

B

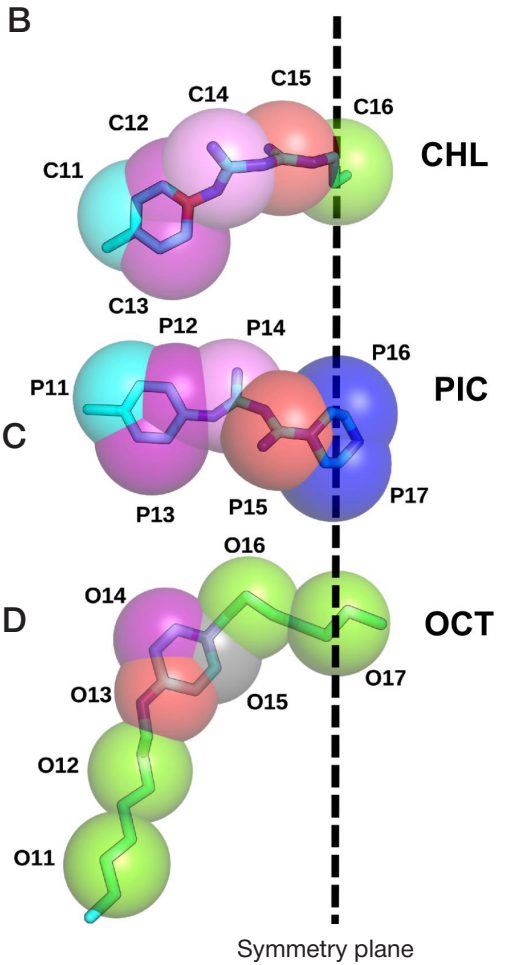

Fig. 1. CA chemical structures with overlapping coarse grains. A. Miramistin (MIR). B. Chlorhexidine (CHL). C. Picloxidine (PIC). D. Octenidine (OCT). Coarse grains are highlighted in different colors in accordance with the particle type selected in MARTINI force field (bottom part of A panel)

profiles as the difference between the positions of phosphate density peaks relative to the center of bilayer. Characteristics of model bilayers for each system were calculated based on two last $\mu$ s of MD trajectory.

\section{RESULTS}

Reduced lipid lateral diffusion coefficients (Fig. 2A), slightly decreased bilayer thickness (Fig. 2B), and increased area per lipid
(Fig. 2C) were observed in the presence of all studied CAs. In the presence of all CA types, except MIR, there was a decrease in lipid fatty acid chain order parameters (no data reported), which could be explained by chemical nature of MIR substantially different from other CAs. Molecules of MIR, having longer hydrophobic regions, penetrated deeper into model bilayer, and their interaction with fatty acid resulted in lipid ordering in the model membrane.

Adding OCT in high concentrations contributed to formation of CL microdomain in the bilayer. Initially, some OCT

A

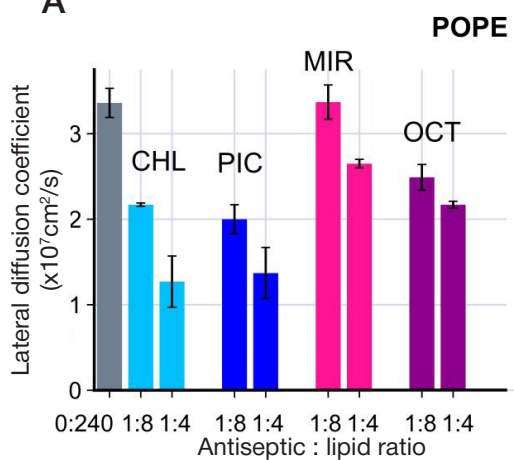

B
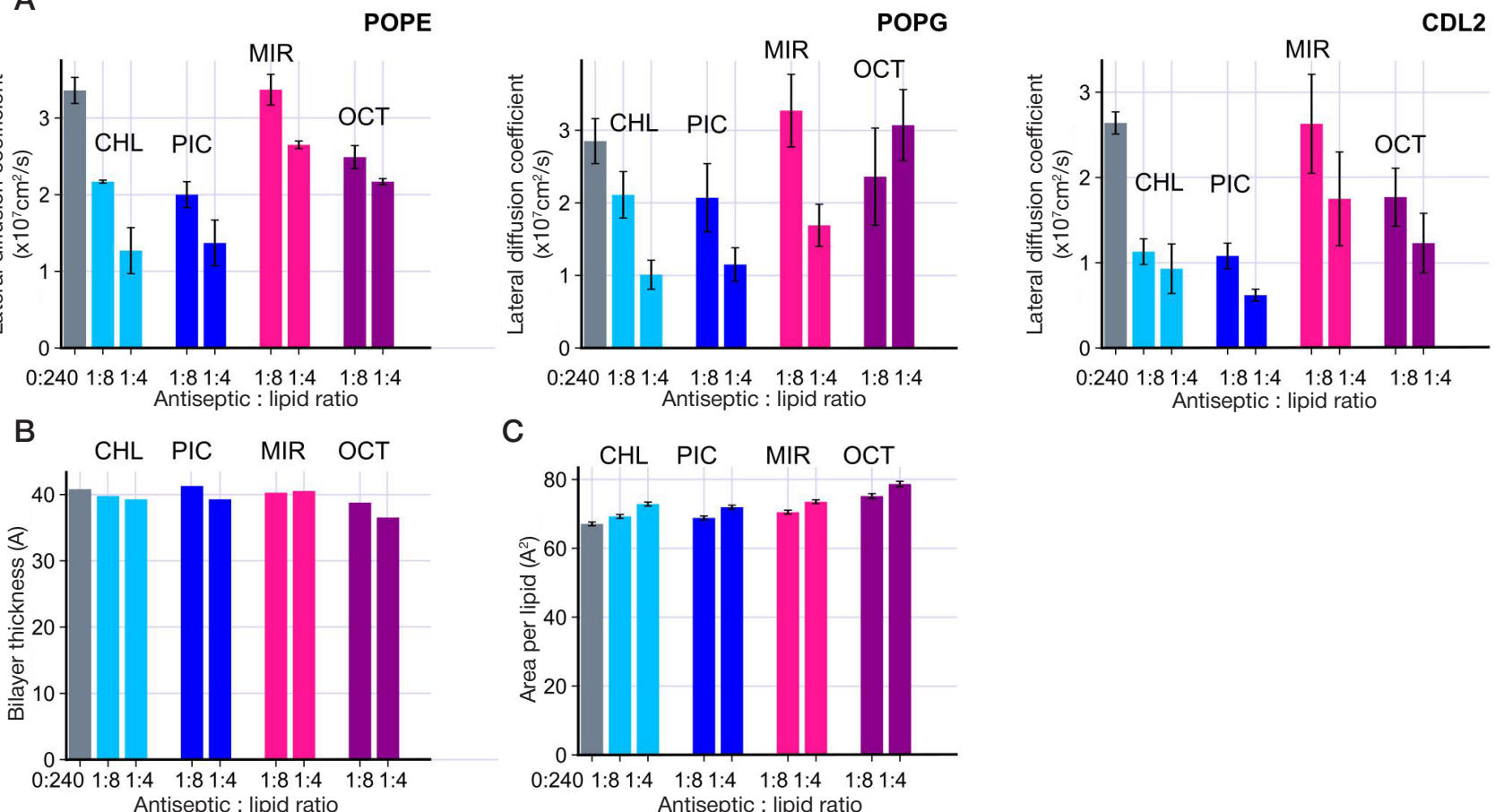

C

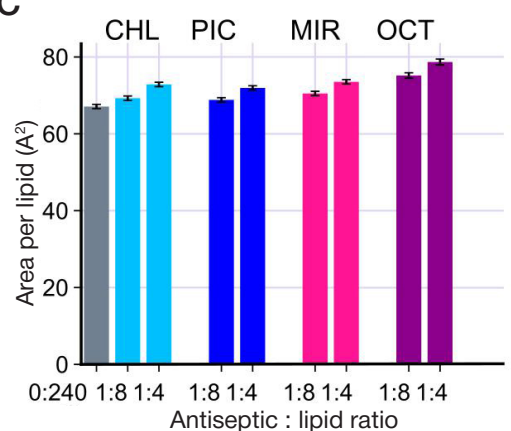

Fig. 2. Characteristics of model membrane comprising POPE:POPG:CDL2 in the presence of various CA concentrations. A. Lateral diffusion coefficients for the following lipids: POPE (left), POPG (centre) and CDL2 (right); B. Bilayer thickness; C. Area per lipid. (Parameter values for model membrane obtained without adding CAs are marked in gray) 
A

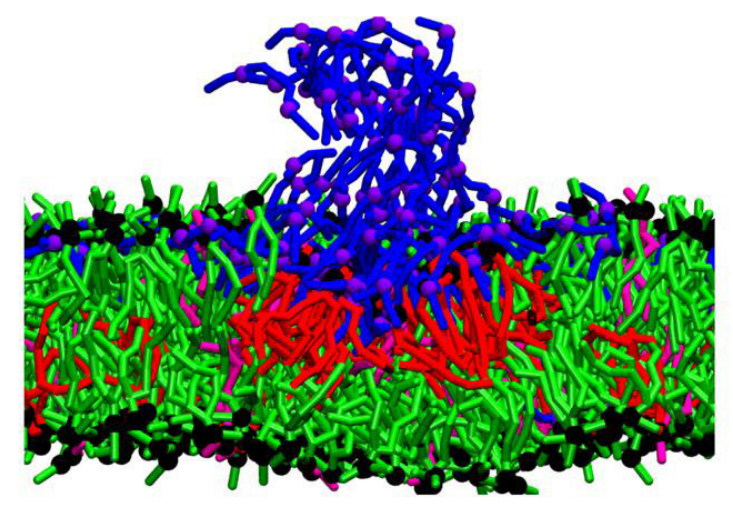

B

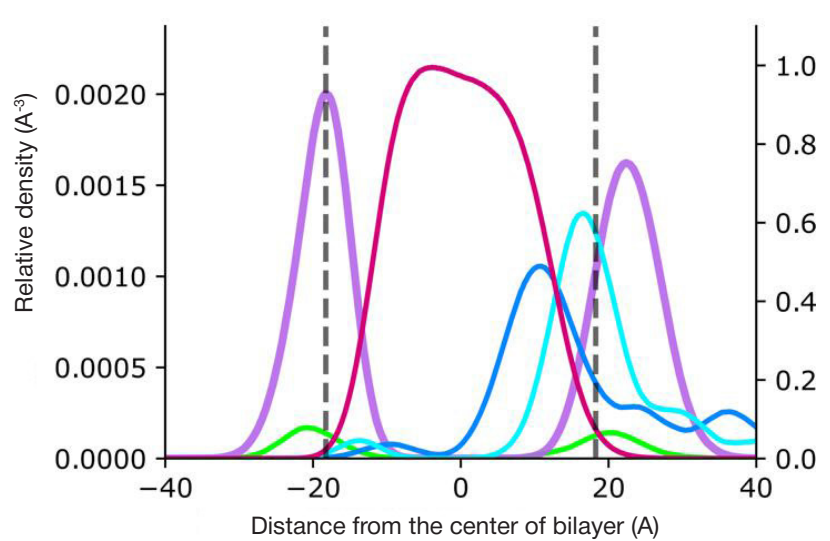

Fig. 3. Effect of CDL2 clustering in the presence of antiseptic OCT at the CA : lipid ratio of $1: 4$. A. Image of MD calculation at time $15 \mu$ s. POPE lipids are marked in green, POPG in pink, CDL2 in red, and OCT in blue. Phosphate residues are marked in black, and charged particles of OCT molecules are marked in purple. B. Density profiles for various components of model membrane. Density profile for lipid fatty acid chains is marked in pink, charged particles of OCT are marked in cyan, terminal OCT particles are marked in light blue, NH3 particle (ethanol) of POPE lipid is marked in purple, GLO particle (glycerol) of POPG lipid is marked in green. Position of phosphates is represented by the dotted lines going through the centers of corresponding peaks. Density profiles for fatty acid chains normalized to the maximum peak value are shown on the second $Y$ axis (right)

molecules integrated itself into the bilayer with subsequent clustering of negatively charged lipids CL and PG. Some OCT molecules, which remained in the "solution", formed a single micellar aggregate quite fast. Such behavior of molecules was due to large number of hydrophobic regions in the molecule of OCT (in addition to terminal end regions, there was a long hydrophobic linker between pyridine fragments). Micellar aggregate sorbed to OCT molecules found on the formed $\mathrm{CL}$ microdomain (Fig. 3A), and remained in this state for a few microseconds. In this case, the symmetry of POPE molecules in outer and inner monolayers was disturbed. The latter was confirmed by displacement of POPE lipid polar head peaks in
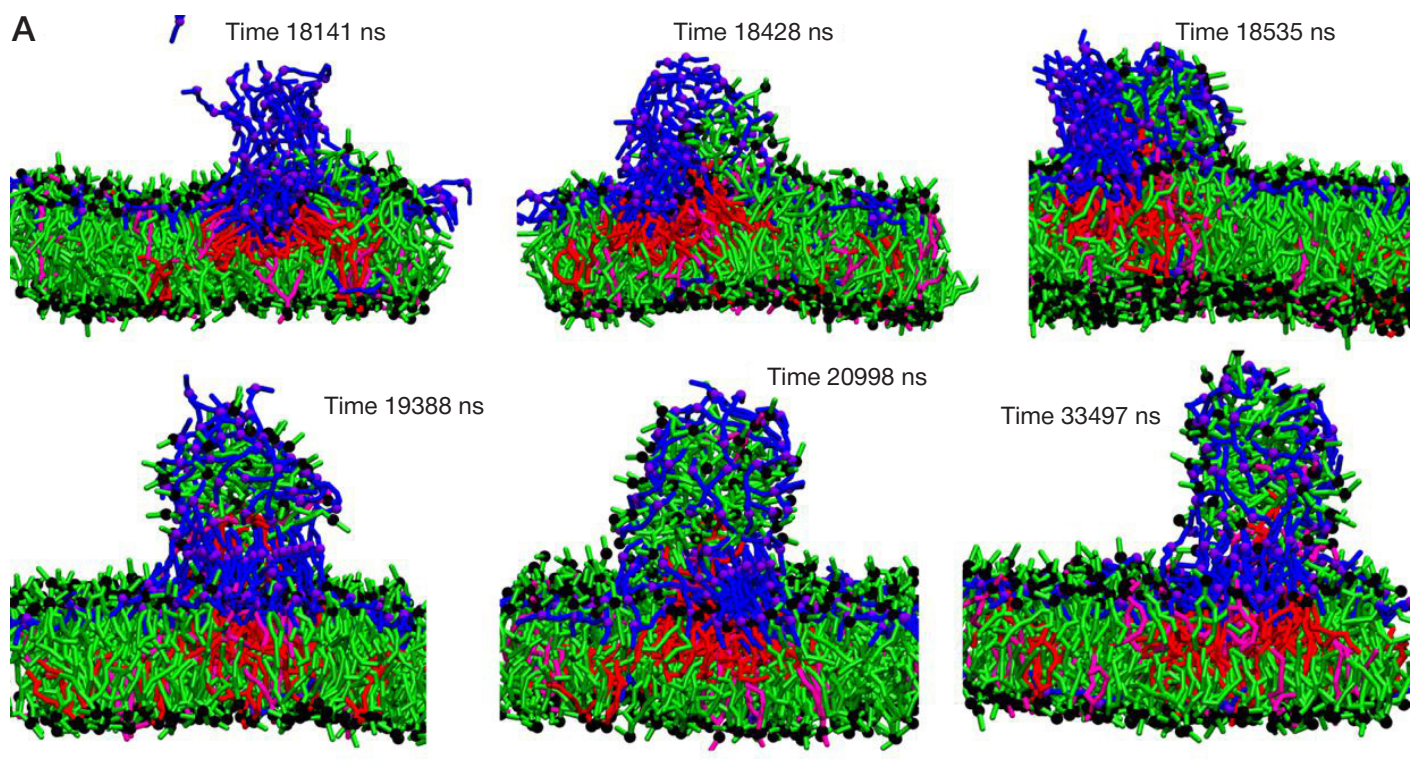

B

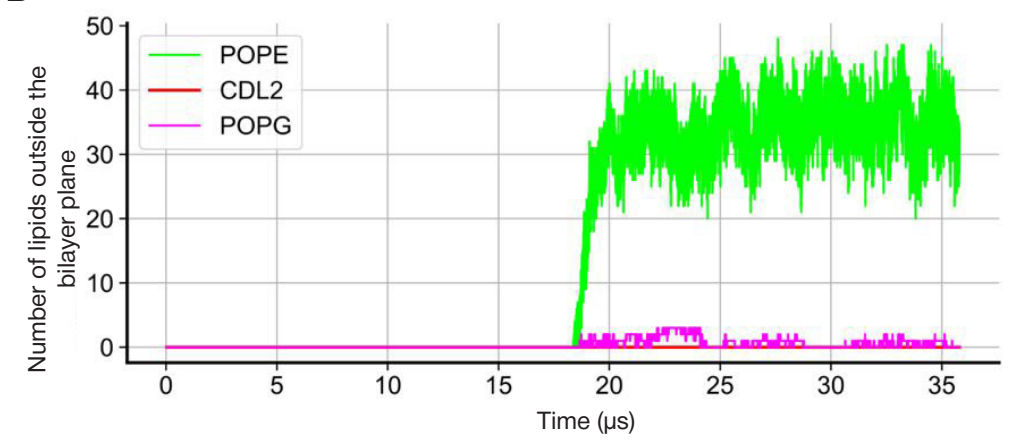

Fig. 4. Effect of pulling lipids out of the model bilayer by OCT molecules. CA : lipid ratio of $1: 4$. A. Consecutive images of MD calculation obtained at different times. POPE lipids are marked in green, POPG in pink, CDL2 in red, and OCT in blue. Phosphate residues are marked in black, and charged particles of OCT molecules are marked in purple. B. Number of lipids pulled out of the bilayer as a function on MD calculation time 
Table. Ratios of phosphatidylethanolamine (PE), phosphatidylglycerol (PG), cardiolipin (CL) in plasma membranes of some species of gram-negative (-) and grampositive (+) bacteria [13, 14]

\begin{tabular}{|c|c|c|c|}
\hline Species & $\mathrm{PE}, \%$ & $P G, \%$ & CL, \% \\
\hline Escherichia coli (-) & 80 & 15 & 5 \\
\hline Yersinia kristensenii (-) & 60 & 20 & 20 \\
\hline Proteus mirabilis (-) & 80 & 10 & 5 \\
\hline Klebsiella pneumoniae (-) & 82 & 5 & 6 \\
\hline Pseudomonas aeruginosa (-) & 60 & 21 & 11 \\
\hline Caulobacter crescentus (-) & 0 & 78 & 9 \\
\hline Staphylococcus aureus (+) & 0 & 58 & 42 \\
\hline Streptococcus pneumoniae (+) & 0 & 50 & 50 \\
\hline Bacillus cereus (+) & 43 & 40 & 17 \\
\hline Bacillus polymyxa (+) & 60 & 3 & 8 \\
\hline
\end{tabular}

the outer monolayer relative to central position of phosphates in the relative density profiles of system components (Fig. 3B). This was due to the fact that phosphates of POPE lipid polar heads located close to $C L$ domain were attracted to micellar aggregate formed by OCT molecules. From the moment after about $18 \mu$ s of MD calculation, POPE molecules located close to $C L$ domain were pulled out gradually (Fig. 4A). The pulling out process lasted approximately $2 \mu \mathrm{s}$ (Fig. 4B).

\section{DISCUSSION}

Plasma membranes of gram-negative and gram-positive bacteria have a different composition. Table presents ratios of three predominant lipids for best studied model species. These data show that PE lipid is the most abundant in the membranes of the majority of species of gram-negative cells compared to gram-positive cells. Usually, CL accounts for no more than 20\% of the total amount, with the exception of species, containing no PE. The contents of $\mathrm{CL}$ in plasma membranes of such species can reach $50 \%$.

Coarse-grained MD calculations showed that all studied CAs were incorporated into the model lipid bilayer. All studied CAs reduced lateral diffusion coefficients both in neutral POPE and in negatively charged lipids POPG and CDL2 (see Fig. 2A). Lipid mobility in fluid mosaic biological membranes [25] plays a vital part in maintaining activity of membrane proteins involved in all cellular processes, such as cell growth and differentiation, transport of substances, and cellular respiration. Lipid mobility is a measure of how easily these biomolecules can move along the plane of bilayer, it is assessed based on lateral diffusion coefficients [26], which could be obtained from the molecular dynamics results [27]. Reduction of lateral diffusion coefficients to $20 \%$ of baseline is observed with the antimicrobial substance : lipid concentration ratio of $1: 5$ [28, 29], which can adversely affect the membrane function.

The most significant reduction of lateral diffusion was observed with respect to CDL2 lipid, having a larger negative charge ( -2 compared to -1 in POPG) and a more massive structure. MIR showed the slightest effect of lateral diffusion reduction. This could be due to the fact that, unlike other studied CAs, molecules of MIR carry a single negative charge and therefore are unable to bind several lipids and form long regions relative to immobilized lipids. Pronounced lateral lipid diffusion slowdown in the presence of biguanides $\mathrm{CHL}$ and PIC can be also attributed to their chemical nature. $\mathrm{CHL}$ and PIC, having the +2 charge and the short linker between the charged particles, contributed to formation of semi-rigid frame, linking the lipids to form the structured areas of the membrane.

When adding all studied CAs, the average thickness of model membrane declined slightly, and the area per lipid molecule increased (see Fig. 2). All antiseptics, except MIR, disrupted packing of lipid fatty acids due to pushing apart acyl chains by their terminal ends embedded in the membrane. Long tail of the MIR molecule is chemically similar to fatty acids of lipids. That is why adding MIR resulted in lipid ordering in the model membrane. The detected changes in the model bilayer may explain the disruptive effect of antiseptics on the bacterial cell plasma membrane function and barrier properties.

Antiseptic OCT contributed to formation of $\mathrm{CL}$ microdomain in the bilayer. Molecules of antiseptic sorbed to this microdomain in the form of micellar aggregate, pulling the adjacent neutral POPE lipids out of the bilayer. Such effects may result in the increased permeability of vesicles after adding OCT, observed during the experiment. The following molecular mechanism of the OCT bactericidal activity was proposed based on the obtained experimental results [30]. Initially, OCT binds to the outer bacterial membrane, causing the surface charge neutralization. Hydrophobic regions of OCT interact with acyl chains of lipid $A$, which results in hydrophobic mismatch, together with disrupted membrane structure and integrity. Likewise, OCT molecules affect plasma membrane, causing membrane depolarization, together with fluidity and phospholipid acyl chain packing impairment. As a result of this nonspecific action, both membranes of cell wall become disrupted, and intracellular fluid flows out of the cell. Our molecular modeling data on the OCT sorption to lipid bilayer, as well as reduced lipid lateral diffusion coefficients and acyl chain order parameters in the presence of OCT support the reported [30] mechanism of this antiseptic bactericidal activity.

\section{CONCLUSIONS}

Interaction of CAs belonging to biguanides ( $\mathrm{CHL}, \mathrm{PIC})$ and QACs (MIR, OCT) with the CL-containing model bilayer, simulating the plasma membrane at the cell poles of bacilliform bacteria, was studied based on the constructed coarse-grain models of these substances. MD modeling results revealed both similarities and differences between the effects of various CAs on the model bilayer. Adding all studied CAs resulted in reduced lipid lateral diffusion coefficients, slightly reduced average membrane thickness and increased area per lipid. 
High concentrations of OCT contributed to CL microdomain formation with subsequent pulling the POPE lipids out of the model plasma membrane. Studying the CA interaction with the model plasma membrane using computer modeling made itpossible to confirm the experimental findings at the molecular level. Comparison of chemically different CAs may contribute to development of effective new medications and enable rational use of antiseptics.

\section{References}

1. Denyer SP, Hugo WB. Biocide-induced damage to the bacterial cyctoplasmic membrane. Soc Appl Bacteriol Tech Ser. 1991; 27: 171-87.

2. Kroll RG, Patchett RA. Biocide-induced perturbations of aspects of cell homeostasis: intracellular $\mathrm{pH}$, membrane potential and solute transport. Soc Appl Bacteriol Tech Ser. 1991; 27: 189-202.

3. Russell AD, Hugo WB. Perturbation of homeostatic mechanisms in bacteria by pharmaceuticals. In: Whittenbury R, Gould GW, Banks JG, Board RG, editors. Homeostatic mechanisms in microorganisms. Bath University Press, Bath, England. 1988; p. 206-19.

4. Fuller SJ. Biocide-induced enzyme inhibition. Soc Appl Bacteriol Tech Ser. 1991; 27: 235-49.

5. Kuyyakanond T, Quesnel LB. The mechanism of action of chlorhexidine. FEMS Microbiol Lett Oxford Academic. 1992; 100 (1-3): 211-15.

6. Cheung, HY, Wong MM, Cheung SH, Liang LY, Lam YW, Chiu SK. Differential actions of chlorhexidine on the cell wall of Bacillus subtilis and Escherichia coli. PLoS One. 2012; 7 (5): e36659.

7. Strakhovskaya MG, Khalatyan AS, Budzinskaya MV, Kholina EG, Kolyshkina NA, Kovalenko IB, Zhukhovitsky VG. Chuvstvitel'nost' antibiotikorezistentnyh koagulazonegativnyh stafilokokkov k antiseptiku pikloksidinu. Klinicheskaja praktika. 2020; 11 (1): 42-48. Russian.

8. Gilbert P, Moore LE. Cationic antiseptics: diversity of action under a common epithet. J Appl Microbiol. 2005; 99 (4): 703-15.

9. Dolgushin FM, Goloveshkin AS, Ananyev IV, Osintseva SV, Torubaev YV, Krylov SS, et al. Interplay of noncovalent interactions in antiseptic quaternary ammonium surfactant Miramistin. Acta Crystallogr Sect C International Union of Crystallography (IUCr). 2019; 75 (4): 402-11.

10. Vereshchagin AN, Frolov NA, Egorova KS, Seitkalieva MM, Ananikov VP. Quaternary Ammonium Compounds (QACs) and Ionic Liquids (ILs) as Biocides: From Simple Antiseptics to Tunable Antimicrobials. Int J Mol Sci. 2021; 22 (13): 67-93.

11. Van Oosten B, Marquardt D, Komljenović I, Bradshaw JP, Sternin E, Harroun TA. Small molecule interaction with lipid bilayers: a molecular dynamics study of chlorhexidine. J Mol Graph Model. 2014; 48: 96-104.

12. Amsterdam D, Ostrov BE. Disinfectants and antiseptics: Modes of action, mechanisms of resistance, and testing regimens. Antibiotics in Laboratory Medicine. Wolters Kluwer Health Adis (ESP), 2014; p. 1135-230.

13. Lin TY, Weibel DB. Organization and function of anionic phospholipids in bacteria. Appl Microbiol Biotechnol. 2016; 100 (10): 4255-67.

14. Epand RM, Epand RF. Bacterial membrane lipids in the action of antimicrobial agents. J Pept Sci. 2011; 17 (5): 298-305.

15. Matsumoto K, Kusaka J, Nishibori A, Hara H. Lipid domains in bacterial membranes. Mol Microbiol. 2006; 61 (5): 1110-17.

16. Strahl H, Errington J. Bacterial Membranes: Structure, Domains,

\section{Литература}

1. Denyer SP, Hugo WB. Biocide-induced damage to the bacterial cyctoplasmic membrane. Soc Appl Bacteriol Tech Ser. 1991; 27: 171-87.

2. Kroll RG, Patchett RA. Biocide-induced perturbations of aspects of cell homeostasis : intracellular $\mathrm{pH}$, membrane potential and

solute transport. Soc Appl Bacteriol Tech Ser. 1991; 27: 189-202. 3. Russell AD, Hugo WB. Perturbation of homeostatic mechanisms in bacteria by pharmaceuticals. In: Whittenbury R, Gould GW, Banks JG, Board RG, editors. Homeostatic mechanisms in microorganisms. Bath University Press, Bath, England. 1988; p. 
206-19.

4. Fuller SJ. Biocide-induced enzyme inhibition. Soc Appl Bacteriol Tech Ser. 1991; 27: 235-49.

5. Kuyyakanond T, Quesnel LB. The mechanism of action of chlorhexidine. FEMS Microbiol Lett Oxford Academic. 1992; 100 (1-3): 211-15.

6. Cheung, HY, Wong MM, Cheung SH, Liang LY, Lam YW, Chiu SK. Differential actions of chlorhexidine on the cell wall of Bacillus subtilis and Escherichia coli. PLoS One. 2012; 7 (5): e36659.

7. Страховская М. Г., Халатян А. С., Будзинская М. В., Холина Е. Г., Колышкина Н. А., Коваленко И. Б. и др. Чувствительность антибиотикорезистентных коагулазонегативных стафилококков к антисептику пиклоксидину. Клиническая практика. 2020; 11 (1): 42-48.

8. Gilbert P, Moore LE. Cationic antiseptics: diversity of action under a common epithet. J Appl Microbiol. 2005; 99 (4): 703-15.

9. Dolgushin FM, Goloveshkin AS, Ananyev IV, Osintseva SV, Torubaev Y, Krylov SS, et al. Interplay of noncovalent interactions in antiseptic quaternary ammonium surfactant Miramistin. Acta Crystallogr Sect C International Union of Crystallography (IUCr). 2019; 75 (4): 402-11.

10. Vereshchagin AN, Frolov NA, Egorova KS, Seitkalieva MM, Ananikov VP. Quaternary Ammonium Compounds (QACs) and Ionic Liquids (ILs) as Biocides: From Simple Antiseptics to Tunable Antimicrobials. Int J Mol Sci. 2021; 22 (13): 67-93.

11. Van Oosten B, Marquardt D, Komljenović I, Bradshaw JP, Sternin E, Harroun TA. Small molecule interaction with lipid bilayers: a molecular dynamics study of chlorhexidine. J Mol Graph Model. 2014; 48: 96-104.

12. Amsterdam D, Ostrov BE. Disinfectants and antiseptics: Modes of action, mechanisms of resistance, and testing regimens. Antibiotics in Laboratory Medicine. Wolters Kluwer Health Adis (ESP), 2014; p. 1135-230.

13. Lin TY, Weibel DB. Organization and function of anionic phospholipids in bacteria. Appl Microbiol Biotechnol. 2016; 100 (10): 4255-67.

14. Epand RM, Epand RF. Bacterial membrane lipids in the action of antimicrobial agents. J Pept Sci. 2011; 17 (5): 298-305.

15. Matsumoto K, Kusaka J, Nishibori A, Hara H. Lipid domains in bacterial membranes. Mol Microbiol. 2006; 61 (5): 1110-17.

16. Strahl $\mathrm{H}$, Errington J. Bacterial Membranes: Structure, Domains, and Function. Annu Rev Microbiol. 2017; 71: 519-38.

17. Mileykovskaya E, Dowhan W. Cardiolipin membrane domains in prokaryotes and eukaryotes. Biochim Biophys Acta - Biomembr. Elsevier B.V. 2009; 1788 (10): 2084-91.

18. Romantsov T, Battle AR, Hendel JL, Martinac B, Wood JM.
Protein localization in Escherichia coli cells: comparison of the cytoplasmic membrane proteins ProP, LacY, ProW, AqpZ, MscS, and MscL. Journal of bacteriology. 2010; 192 (4): 912-24.

19. Camberg JL, Johnson TL, Patrick M, Abendroth J, Hol WG, Sandkvist M. Synergistic stimulation of EpsE ATP hydrolysis by EpsL and acidic phospholipids. The EMBO journal. 2007; 26 (1): 19-27.

20. Kholina EG, Kovalenko IB, Bozdaganyan ME, Strakhovskaya MG, Orekhov PS. Cationic antiseptics facilitate pore formation in model bacterial membranes. The Journal of Physical Chemistry B. 2020; 124 (39): 8593-600.

21. Qi Y, Ingylfsson HI, Cheng X, Lee J, Marrink SJ, Im W. CHARMMGUI martini maker for coarse-grained simulations with the martini force field. Journal of chemical theory and computation. 2015; 11 (9): 4486-94.

22. Marrink SJ, Risselada HJ, Yefimov S, Tieleman DP, De Vries AH, et al. The MARTINI Force Field: Coarse Grained Model for Biomolecular Simulations. J Phys Chem B. 2007; 111 (27): 7812-24.

23. Abraham MJ, Murtola T, Schulz R, Pall S, Smith JC, Hess B, et al. GROMACS: High performance molecular simulations through multi-level parallelism from laptops to supercomputers. Software X. 2015; 1: 19-25.

24. Yesylevskyy SO, Schäfer LV, Sengupta D, Marrink SJ. Polarizable water model for the coarse-grained MARTINI force field. PLoS computational biology. 2010; 6 (6): e1000810.

25. Singer SJ, Nicolson GL. The Fluid Mosaic Model of the Structure of Cell Membranes. Science. 1972; 175 (4023): 720-31.

26. Macháň R, Hof M. Lipid diffusion in planar membranes investigated by fluorescence correlation spectroscopy. Biochimica et Biophysica Acta (BBA)-Biomembranes. 2010; 1798 (7): 1377-91.

27. Moradi S, Nowroozi A, Shahlaei M. Shedding light on the structural properties of lipid bilayers using molecular dynamics simulation: a review study. RSC Adv. The Royal Society of Chemistry. 2019: 9 (8): 4644-58

28. John T, Thomas T, Abel B, Wood BR, Chalmers DK, Martin LL. How kanamycin $A$ interacts with bacterial and mammalian mimetic membranes. Biochimica et Biophysica Acta (BBA)Biomembranes. 2017; 1859 (11): 2242-52.

29. Berglund NA, Piggot TJ, Jefferies D, Sessions RB, Bond PJ, Khalid S. Interaction of the antimicrobial peptide polymyxin B1 with both membranes of $\mathrm{E}$. coli: a molecular dynamics study. PLoS computational biology. 2005; 11 (4): e1004180.

30. Malanovic N, Ön A, Pabst G, Zellner A, Lohner K. Octenidine: Novel insights into the detailed killing mechanism of Gramnegative bacteria at a cellular and molecular level. Int J Antimicrob Agents. 2020; 56 (5): 106146. 